\title{
International Accounting Harmonization Process of IASB in Financial Organization
}

\author{
Dr.Ariet MALAJ, \\ College University of Business Tirana Albania,Vangjel Noti,Tirane
}

\begin{abstract}
The international harmonization of Accounting Standards is a process, which brings international Accounting Standards into some sort of agreement, in order to achieve a common set of Accounting principles. 7000 European companies have to use the International Accounting Standards (IAS) in the European Union (EU), beginning 2005. The IAS are developed from the IASB. Furthermore, the long existing rejection of IAS of the U.S. seems to change. Co-ordination of agendas of the American standard-setting board (Financial Accounting Standard Board (FASB) and the IASB have been announced. We conclude, that the IASB plays a major role in the field of international harmonization. Keywords: Harmonization, International Accounting Standard Board (IASB), International Accounting Standards (IAS), Accounting Standards, International Accounting.

Keywords: Harmonization, International Accounting Standard Board (IASB), International Accounting Standards (IAS), Accounting Standards, International Accounting

DOI: $10.7176 / \mathrm{RJFA} / 11-17-05$

Publication date:October $31^{\text {st }} 2020$

\section{Introduction}

International businesses are no longer confronted only with Accounting problems, which end at domestic borders. When companies cross borders they are confronted with new cultures, challenging new laws and different political systems. Besides that international companies must deal with different Accounting Standards abroad. For example in Germany companies use the German standards (Handelsgesetzbuch). In America, companies have to use the U.S.- Generally Accepted Accounting Standards (U.S.-GAAP).
\end{abstract}

1.1 The role of the IASB in the harmonization process

In the literature used the IASB plays an important role in the harmonization process. However, in the following I will analyze the role of the IASB in the harmonization process. The work, challenges and weaknesses of the IASB will be taken into account.

Efforts and achievements

The following points will describe the IASB's efforts and achievements:

a) Development of 33 Accounting Standards

b) Cooperation with national standards

c) Support of IOSCO (International Organization of Securities Commissions)

d) EU rules

e) Cooperation between the IASB and the FASB

a. Development of 33 Accounting Standards

The IASB has quickly developed 33 standards which have been used on a relatively wide scale. The IASB has encouraged countries without Accounting Standards to use IAS and eliminate changes to IAS. On the one hand many Latin American or Asian countries do not allow the use of IAS. On the other hand with EU rules, IAS will be accepted in 15 countries.

b. Cooperation with national standards

As seen in previous chapters, the IASB has made a series of efforts to work with national standards. Initially, we have eight national standards which are presented to the Board of the International Accounting Standards Committee (IASC). Here, they have the opportunity to be active in promulgating and reviewing International Standards. Second, as I explained above, the efforts of a binding process made possible the participation of a variety of individuals and organizations such as national standards, financial analysts, scholarship holders or users of financial statements.

c. IOSCO support

IOSCO's recommendation to its members to allow multinational companies to use IAS in cross-border activities was an important step towards the worldwide acceptance of IAS.

IOSCO opened the door for IAS to be used by companies to be listed in international capital markets. All member organizations must accept companies that prepare financial statements in accordance with IAS. On the other hand IOSCO members can request additional information. As explained, IAS has only a recommendatory character. Therefore, the IASB needs the support of other bodies to enable the acceptance of the standards, and this was done by the support of IOSCO in 2000. 
d. EU rules

The EU will require all listed European companies to prepare consolidated declarations in accordance with the 2005 IAS. In Chapter Four we can see a continuous movement of the EU towards the IAS. For the first time in 1995, the EC decided to support the IASB, joining its Consultative Group with the decision not to develop its own standards. Various factors may have played a role in making this decision. First, it may have been an EU "no" to US-GAAP in Europe. The decision may be explained initially by the fact that there is no possibility of US-GAAP being influenced by the European position. On the contrary, as explained above, the EU has several possibilities to influence the work of the IASB. Second, it can be interpreted as a European response to the negative traditions of US regulators (eg SEC, FASB). US-GAAP have been admitted to Europe without objection. European companies in contrast can only be listed on US stock exchanges with a full preparation of US-GAAP compliant financial statements, or in accordance with US-GAAP compliant IAS.

e. Cooperation between IASB and FASB

The IASB and FASB (Financial Accounting Standards Board) statement to work together to establish a single set of global accounting rules in 2002 was another step towards the adoption of IAS. The American Capital Market is considered to be the most important in the world. A smooth acceptance of IAS in this market would motivate companies as regulators of other countries to consider using IAS. As the IASB needs consistent assistance from other bodies to carry out its task, it is not surprising that the IASB agreed to add a short-term project to the FASB to its agenda. Its purpose is to eliminate differences between standards (IAS v. US-GAAP). In the short term, the IASB and the FASB set out to work on individual projects which would reduce these differences. Eventually, they agreed to work together and make their agendas the same for the future (IASB, 2002). This can be seen as a change in the way the FASB and US regulators think. Until the announcement of a close operation, the FASB insisted that an approach would only take place on the basis of US-GAAP. He also stated that US standards are the best in the world and that he would not accept any other lower quality standard (eg IAS). However, it appears that the FASB and US regulators (eg the SEC) are now more flexible on this issue. Or, we can imagine that the IASB would have to make a lot of compromises in order to achieve IAS acceptance in the United States.

From my point of view two factors have convinced the FASB to cooperate with the IASB. First, is the EU decision to use the IAS. With this rule IAS will be the official Accounting Standards for the more than 7,000 EU companies listed in 2005. Secondly, I think the scandals in the US have reduced American confidence in their Accounting Practices. Thus, the declining confidence of Americans in their rules and the strong support of the EU may make possible a compromise in the internationalization of Accounting Standards.

Weaknesses of the IASB

I consider the following points as weaknesses of the IASB.

a) The IASB's close relationship with the philosophies of the Anglo-American Model.

b) Approximation means only harmonizing IAS and US-GAAP.

c) Developed countries are negligible.

a. The IASB's close relationship with the philosophies of the Anglo-American Model

As stated the IASB standards belong to the Anglo-American Model. The organization was formed in 1973 without the initiative of Canada, the United States and the United Kingdom in order to prevent the Continental-European Model Accounting Philosophies from gaining much power (Dorner and Wollmert, 1995). It is therefore not surprising that the IASB has been criticized for having a close relationship with the United States. It has been argued that the IASB secretly propagates principles of the Anglo-American Model (Maier-Siegert, 2001). IOSCO support corroborates this argument. Kleekamper states that IOSCO support was only possible because mainly Continental-European suffrage had been eliminated and US US rules were preferred (Kleekamper, 2002). Continental-European options were canceled because at the time of IOSCO Support, the IASC (IASB predecessor) was influenced by American members. IOSCO was mainly influenced by the SEC (Kleekampler, 2002). Achleitner is of the opinion that the IASB has been closely associated (or favored) with the American Accounting Philosophy in order to obtain IOSCO Support (Achleitneir, 2000).

Another aspect that argues that Americans and other Anglo-Saxon Model countries primarily influence the IASC Foundation will be seen when Board members and Trustees are considered. The structure of the IASC Foundation is presented. As explained above Trustees appointed the members of the Board and the members of the Board have the primary authority to amend and develop the Accounting Standards. If we look at the 19 members of the Trustee, 5 are from the US. All other countries are represented by only one member, except Japan which is represented by 2 members. However, the influence of the United States is clear, it is stated that Trustees represents a fair presentation of the Anglo-American and Continental-European Model (6 out of 19 members are European). What was seen by the 14 members of the Board? There are only 4 members from the US, all other countries are represented by one member, except the UK which is also represented by four members. Here we do not have a fair representation of the members of the Anglo-American Model and the Continental-European Model ( 4 of the members are European). The Anglo-American Model countries represent 10 voices, while the others 4. It is also noted that all four Board members from the US were involved in a manner with the FASB prior to their 
appointment. Therefore, I see certain contradictions in the rules set to appoint IASB members. It states that Trustees should appoint members, in order to ensure that it will not be dominated by any area or regional interest. b. Approach means only harmonizing IAS and US-GAAP

Various authors (eg Buchheim, 2002) talk about an approach of IAS and US-GAAP as the main activity of the IASB in the future. I see the risk of such a development that would be contrary to the IASB's goal of "bringing it closer to National Accounting Standards" (Epstein and Mirza, 2001). This will disregard the standards of other countries. In my opinion such a development would be positive for an international acceptance of IAS.

US-GAAP do not conform to EU directives (Kleekamper, 2002). If the IAS and US-GAAP are aligned, there will be criticism from Europe, because then the IAS will not conform to EU directives. Such a development will bring conflict in the arena of harmonization. On the other hand I think that in order to achieve a harmonized global set of Accounting Standards all participants should accept the changes in their old system.

c. Developed countries are negligible

Members of the IASB as well as Trustees are mainly from Western countries (eg Europe, US, Canada and Australia). Therefore, one can criticize the under-representation of developed countries in the development of international standards. Care should be taken in presenting the interests of developed countries to the IASC Foundation Board.

IASB Achievements

Having considered the work and weaknesses of the IASB, I would like to discuss its achievements. These are:

a. Mixing Accounting Philosophies between countries

b. Interpretation and supervision of IAS

c. Purposes of the IASB

d. Admissibility of IAS by the SEC

e. Lobbying at the IASB

a. Mixing Accounting Philosophies between countries

One effort the IASB will make in the process of international harmonization is the differences between countries.

They are based on the different Accounting Philosophies explained in the chapter above. These changes in Accounting Practices are the result of several specific environmental factors that have divided them. The result of the harmonization process can not be a copy of either the Anglo-American or the Continental-European model. The Anglo-American model is difficult to implement in the short term for many economies around the world. For example, it will be difficult for Germans to enforce the various company laws in the American system, which considers only a deviation from listed and unlisted companies. The Continental-European model will also not be accepted because of its non-managerial orientation or because of the legal obstacles it presents.

Moreover, as I explained above, in most Continental European countries professional accounting organizations do not have the responsibility or authority to set Accounting Standards. Such issues are beyond the responsibility of the government and the law. This is in contrast to the situation in most Anglo-American countries, where the accounting profession is more influential in the standards-setting process. To overcome all these problems, an International Model has been suggested, which contains elements of different Accounting Practices. In my view an international organization such as the IASC is needed in order to combine different Accounting Philosophies and develop an International Model (IAS). One of the IASB's next tasks is to reduce the differences between the Accounting Standards, and specifically those between IAS and US-GAAP. The United States is one of the most important capital markets and I think it will take time for this market to be open to IAS.

b. Interpretation and supervision of IAS

"It is one thing to write about Accounting Standards. It is quite another to interpret them and apply the principles to the standards for the billions of transactions that take place in the business world. This is especially true if the standards provide general principles." (Turner, 2001)

I explained above that IFRIC (International Financial Reporting Interpretations Committee) is responsible to the IASC Foundation for the interpretation of IAS. A critical fact of IASB standards is the poor interpretation of IAS. Since IASs are the basic principles of standards it is necessary for further interpretation. This can be ensured by those who prepare, auditors and regulators such as the SEC. The interpretation made by different interpreters, preparers, auditors and regulators, poses a challenge to ensure an approximation with the interpreters of the standards.

Imagine: IASs can be projected by the SEC as Accounting Standards to be listed on the US capital market. First, the standards will be interpreted at IFRIC. And at a second level, the SEC will interpret them because it will ensure investor protection and the efficient functioning of the capital market. As a result, I see another challenge for the IASB to answer the question: What steps can and should be taken for IAS to be interpreted effectively and uniformly around the world?

Another essential precondition for the acceptance of IAS is that there are not only high quality standards but also that their implementation is supervised. If there is no body that monitors the implementation of standards then there is a risk that the standards are interpreted and applied differently. The problem of control cannot be solved 
by the IASB alone, because it does not have the power of sanctions. Tuner suggests a defense infrastructure in order to solve the control problem. Such a protective structure consists of:

- High quality accounting and auditing standards.

- Active regulatory oversight.

- Audit firm

c. Purposes of the IASB

Talking about the challenges of the IASB also involves considering the goals of this body. I have shown these objectives above. The IASB aims to develop a single global set of Accounting Standards and works for international use and application of IAS. The IASB has published 33 Accounting Standards. However from my point of view it would be unwise and unjustified to talk about a global acceptance of IAS. First, access to the US market is not possible for companies currently using IAS. Second, IASs are not allowed in some Asian countries (eg Korea, Japan, Malaysia, Singapore and Indonesia), in some South American countries (eg Argentina, Brazil, Chile, Colombia and Mexico) and they are not accepted. in African countries (eg Burkina Faso or Ghana). However, IASs have been accepted in many other countries. EU rules and the declarations of Australia and Canada to accept the IAS in 2005 will attract other countries. This will bring the IASB a major step towards achieving its goals.

The third purpose of the IASB is to bring National Accounting Standards closer to IAS. I consider this goal as very challenging. It will be difficult to place under one umbrella all the opinions of the national standards that represent the different Philosophy of Accounting. In conclusion I can say that I am very curious about achieving these objectives.

d. Admissibility of IAS by the SEC

As a result of the high quality of financial information ensuring an efficient market, Currency Market regulators are particularly interested in presenting Accounting information. They can accept or deny a company access to the market. I have already argued that IASs are not fully acceptable in the US capital market. The SEC accepts IAS in accordance with US-GAAP. This is consistent with IOSCO support. Other developments such as: Enron, EU rules and the improvement of the quality of IASs have led to a better and more open opinion of the SEC regarding IAS. However, the SEC is of the opinion that the capital market in the US is very efficient, as a result of its high quality financial reporting. Therefore, it is not possible to accept lower quality standards. It will be interesting to see when and if the SEC accepts IAS. In addition, time will tell if the SEC will accept them all immediately or step by step as long as they are consistent with US-GAAP.

The SEC will reconsider the need for EU member states to continue complying with IASs with US-GAAP if by the end of 2005 there has been progress in:

- Improving and short-term approach to Accounting Standards.

- Development in a consistent interpretation and application of IAS.

- Establishment of financial reporting infrastructure.

Meeting these SEC requirements will be a challenge for the IASB.

Send feedback

e. IASB lobbying

In order to protect their own interests, many actors (national standards-setting bodies, companies, governments) try to influence the work of the IASB. I will give two examples of what kind of lobbying activities can be.

A good example is the Swiss company Novartis which considered changing from IFRS to US-GAAP, if the IASB does not change its standards "this would require depreciation of goods over 20 years". It was said that Novartis was concerned that this would turn into a strategic disadvantage if the IASB did not adopt a standard for goods approaching the Financial Statement of Accounting Standards No. 142 of the FASB.

Another possible political interference in the work of the IASB may come from the EU control mechanisms presented above. This mechanism evaluates the international standards adopted by the IASB, to give them legal support for use in the EU. Legislative support for the IAS in the EU can be seen as a challenge for the IASB, as the EU may rewrite the IAS to suit regional needs in European countries. In my view, this would undermine the IASB's objective of developing common international accounting standards. In addition, it is possible that other regulators, considering how they will react to the IASB, will adopt the support mechanism as well. For this reason there is a risk of political influence in the EU.

\section{Conclusions on the role of the IASB}

On the one hand we see the "official" role of the IASB, which is the international development of the acceptance of Accounting Standards. Although their global acceptance has not yet been achieved, I believe they will gain importance in the coming years. Opponents of the IASB may suspect that the IASB is the main player in the field of harmonization. However, it can not be denied that they play an important role in the harmonization process, because its standards are supported by most organizations such as the EU, IOSCO. An accession of the SEC and the FASB is possible in the future.

On the other hand we see the role of the IASB as an intermediary between different Accounting Standards 
and Philosophies. I consider the IASB's efforts to be an important step in overcoming the changes in National Accounting Standards. It tries to combine the opinions of different actors who set standards by inviting them to participate in this organization as a mandatory process. The IASB seeks to bring the various national Accounting Standards closer together and will develop the adoption of a global set of Accounting Standards. However, we are aware that the IASB needs ongoing support in order to be able to fulfill its role. The IASB does not have full legal force. Therefore, compliance with IASB standards is not mandatory. Thus, the IASB depends on national organizations and actors that set standards for the international acceptance of IASs. Here we see the main weaknesses of the IASB. We can also find the reasons why the IASB is trying to work so closely with other organizations.

Current state of the harmonization process and future perspectives

The year 2002 was very busy but a successful period for the harmonization process. It seems very interesting to summarize what has been achieved during this process. In June 2002 the EU Council of Ministers issued a rule that all companies listed in the EU regulated market were supposed to prepare financial data for 2005 in accordance with IAS. In addition, a great hope for harmonization was the decision of the FASB and the IASB to work together, which was announced in September / October 2002. The International Standards adopted in the United States will be a major change in the process. of harmonization. However, time will tell how successful this collaboration between these accounting bodies will be.

This topic has shown that the IASB plays an important role in the harmonization process. Since these organizations use standards it is justified to ask if it is still appropriate to use the term harmonization for this process. As explained in Chapter Four, standardization does not account for national differences. Each country has its own set of rules and Philosophy of Accounting, it will try to defend its procedures against a set of unknown standards, which they will be forced to use. I see the advantage of harmonization from the fact that it knows the national resources of each country and tries to keep them secret from other countries.

However, while there is still a choice of IAS and it is not possible to impose IAS in every country, one should not talk about a standardization process. At least I think this is true of the international process. EU development, which recommended IASs in early 2005 , is considered to be a standardization process.

I have, however, mentioned that I see the risk that this approach means that the IASB will only bring IASs closer to US-GAAP. I believe that if this is done, other countries will be forced to use these standards. A development of this kind will be more akin to standardization, with the disadvantages described above.

When discussing the harmonization process, its perspectives should also be taken into account. It is a comment from AICPA (American Institute of Certified Public Accountants) that gives a good idea of the prospects in the field of accounting. "All accounting systems, including US-GAAP, evolve over time and require improvements. As IASs and national systems move closer to high quality standards, over time there will be fewer incompatible points. and in the future, compliance will be unnecessary. " (SEC, 2002)

IASs have a good chance of becoming global standards for consolidated financial statements. First, they are accepted in some capital markets (eg Germany, Austria and Hong Kong) and will be accepted in other countries, because the democratic work of the IASB will bring good support to IAS. Second, I think the advantages of a single set of Accounting Standards given in Chapter Four will convince preparers and users as well as regulators. Greater acceptance of IASs is expected in the US once the differences between US-GAAP and IASs are overcome. International recognition will be achieved through cooperation between those who set standards.

National choices in measurement / valuation methods, as well as national characteristics as the pairing of tax law and commercial law will be confused in our minds, in order to achieve international similarity and comparability of financial statements.

\subsection{Criticisms of the harmonization process}

A discussion on the harmonization process will include the advantages and disadvantages of this process. In the above chapter I have written about the benefits of the harmonization process, where criticisms about it are taken into account. I have shown in Chapter Three that International Standards are part of the surrounding national environment, which is different for each country. There are concerns that International Accounting Standards do not conform to the specific environmental environment of each country. It is uncertain whether international standards can sustain change based on different national traditions and environments. This is due to the fact that global standards are not of the same extent included in the national environment as national standards and therefore can not react according to national circumstances. Different Accounting Practices have been developed to serve the needs of many different users. Therefore, their efficiency will be reduced.

I argued above that the main advantage for financial data users will be better comparability of data. On the contrary, the question arises, whether harmonized Accounting Standards are currently necessary for participants in the capital market?

To understand such rules, knowing them in detail is necessary. Not all analysts understand the role of the IASB. Therefore, I think it is important for the IASB to work for a better understanding of the standards. 
Comparability with competitors is necessary for the analyst to make comparisons.

A statement made by Goeltz is that global capital markets would have developed even without International Accounting Standards. Goeltz seems to be right in this respect. On the other hand, it is clear that the need for receipt or full preparation of financial statements in accordance with Foreign Accounting Standards is an obstacle to free capital competition.

The achievements, challenges and weaknesses of the IASB are presented. From this it follows that the IASB plays an important role in the field of international harmonization. This can be explained by its achievements. I see as a key challenge for the IASB the need for a global imposition to promote the uniform application of IASs. I think that in order to achieve the goal a uniform interpretation and monitoring of standards is needed. This assumes that all actors involved (companies, auditors, government, regulators and standard-setters) work together. I think this is the harmonization / approximation of Accounting Standards, which will lead to a global and uniform acceptance of a single set of Accounting rules. I think that all actors who set standards will agree on a single answer, of a high quality. In order to meet the objective, preparers and users of financial statements will be willing to accept that the harmonization / approximation of Accounting Standards will involve changes to the entire existing system. A comparability of financial statements has been described as an advantage of Unified Accounting Standards. On the other hand, the question arises, is an international harmonization of Accounting Standards possible, without a harmonization of the socio-economic environment at the same time.

\section{A brief summary}

3.1 What is the process of international harmonization of Accounting Standards?

The process of international harmonization has been termed as bringing together National Accounting Standards to achieve certain types of internationally accepted principles, according to which financial statements are prepared. In accordance with this set of internationally accepted standards, the comparability of financial data must be achieved.

Comparable, transparent and reliable financial information is important for an efficient and integrated capital market. Lack of comparability will discourage foreign investors due to uncertainty over the credibility of financial statements. It is explained that the advantages (eg cost savings, better opportunities to make comparisons) for users and compilers of financial reports have created the need for harmonized international accounting standards on which financial reports will be based.

The starting point of the reconciliation process can be found in the changes in Accounting Practices. We have differences between these two worlds: the Anglo-American and the Continental-European. I argue that the movement and uniformity in Accounting Standards has to do with resolving the conflict that results from changes in Accounting Philosophies.

The harmonization process began in the 1960s and is still ongoing. From this he concludes that it is a very complex process which was and is still full of controversy between the countries and organizations involved in it. In 1973 the predecessor of the Board of Accounting Standards was formed. This international body was designated to develop Accounting Standards for International Use. These accounting standards are called IAS. Most of them took place between 1973 and 1987. During 1987 and 2000 the harmonization process was mainly influenced by the IASB and IOSCO agreement to compile a list of IASs allowed for companies. international listed on international stock exchanges. IOSCO recommended this list of Basic Standards to its 2000 members. This was an important step in the harmonization process. The IASB has achieved better results in the harmonization process, but it is still difficult and highly demanding to accept the standards. However, it seems that we have never been so close to harmonized Accounting Standards as in 2002.

3.2 What is the current state of the harmonization process?

In 2002, organizations involved in the international harmonization process could make some claims for an agreement. This gave hope that it would be easier for investors, regulators and companies to understand the financial statements worldwide for the future. First, we had the EU statement that all companies listed in the EU had to prepare financial data in accordance with IAS 2005. This means that over 7000 European companies use IAS, starting from year 2005. In addition, the continuing rejection of US IASs began to change. IASs would be admitted to the Australian and Canadian stock exchanges without difficulty in 2005. Therefore, I conclude that the IASB standards are more widely accepted and are considered to be of a higher quality than before.

3.3 What is the role of the International Accounting Standards Board in the harmonization process?

The official role of the IASB is to develop international acceptance of Accounting Standards. Its purpose is to formulate standards and promote their global use and acceptance. The predecessor of the IASB was not very successful and the standards were not globally accepted. Therefore, in the 1990s he undertook a collaboration with IOSCO to develop some standards that would be accepted worldwide.

In the late 1990s the IASC reorganized its structure and process of developing Accounting Standards. The 
IASB focuses heavily on collaboration with standard-setting actors and a high involvement of stakeholders and organizations when IASs are developed. The IASB has the role of a mediator between two Accounting Philosophies, called the Anglo-American and Continental-European Model. Both worlds of Accounting want to avoid a dominance of the other side and the IASB will find a compromise solution that will satisfy both parties. However, I have illustrated that the IASB is influenced by the Anglo-American model. Thus, it is doubtful whether the IASB will serve as a mediator.

The IASB has made significant advances in the comparability of financial statements. The long-standing US stance on non-acceptance of IAS has been negative for a harmonization process. I consider the achievements of the IASB (EU rules, the agreement between the FASB and the IASB) as the biggest change in the process of international harmonization. And therefore the role of the IASB is very important in it.

\section{Conclusion}

In this study I explained the process of harmonization until recent years. In the future it is important to observe other developments in this field. In particular, the coming years will show how effective the agreement between the IASB and the FASB will be. These years will show whether the two bodies will be able to keep their agreements in closer cooperation, or if nothing will change. Therefore, another study should be done after five or ten years to show subsequent developments.

This study was done from the perspective of the actors involved. Another possibility could have been to consider the opinion of the affected companies. In other words, it might have been interesting to find out how many companies are preparing for such accounting developments. Differing opinions between small and international enterprises could have been taken into account.

\section{References}

Publications in text form by the CCC,

IAS / IFRSs issued by the NQF:

IAS 26 - Accounting and Reporting from Pension Benefit Schemes,

IAS 29- Financial Reporting in Hyperinflationary Economies,

IAS 33 - Income per Share,

IAS 34- Interim Financial Reporting

IAS 39- Financial Instruments - Recognition and Measurement; and

IFRS-2- Share-based payments,

IFRS 4 - Insurance Contracts,

IFRS 6 - For the use and assessment of mineral resources,

IFRS - 7 Financial Instruments - Disclosures,

IFRS 8 - Operating Segments

Articles on IAS, related to financial reporting, cost accounting and analysis of financial statements, published in the journal "Accounting, Finance \& Auditing"

Other online materials.

Choi, F .; Mueller, G. (1992): International Accounting, Prentice Hall, New Jersey, $2^{\text {nd }}$ Edition.

Cooke, S .; Rivat, L .; Faarborg, M .; Pacter, P. (2001): ACCOUNTING STANDARDS, International Tax Review,, Vol. 12, Issue 7.

Law on Accounting and Financial Statements no. 9228 dt. 29.04.2004, with changes www.minfin.gov.al, Regulation (CE) n. 1606/2002 of the European Parliament and of the Council, of 19 July 2002

"Guide to International Accounting Principles - 1 The IAS Balance Sheet Editing” A.Portalupi Journal of Business \& Economic Policy Vol. 2, No. 2; June 2015

http://www.diva-portal.org/smash/get/diva2:18878/FULLTEXT01.pdf 